\title{
THE STATE TRIBUNAL AS A SPECIAL ORGANIZATION ADJUDICATING ON THE CONSITUTIONAL RESPONSIBILITY OF THE PRESIDENT ${ }^{1}$
}

\author{
O TRIBUNAL ESTADUAL COMO ORGANIZAÇÃO DE JUDICIALIZAÇÃO DA \\ RESPONSABILIDADE CONSTITUCIONAL DO PRESIDENTE
}

Sabina Grabowska ${ }^{2}$

\section{RESUMO}

A criação de um órgão especial cujo único propósito é julgar as violações da constituição ou da legislação por funcionários da cúpula do Estado, inclusive pelo presidente, é relativamente raro. Somente a Grécia e a Polônia implementaram tal solução e até recentemente também o direito francês criou essa possibilidade, mas uma emenda à constituição em 2007 alterou a legislação com esse escopo. O objeto desse estudo é a análise da regulamentação polonesa referente ao Tribunal Estadual no contexto em que a Assembleia Nacional adota a resolução para colocar o presidente no controle de cometer ilegalidades constitucionais.

Palavras-Chave: Tribunal Estadual; judicialização; presidente; responsabilidade constitucional

\section{ABSTRACT}

The creation of a special body whose sole purpose is to rule on violations of the constitution or statutes by senior state officials, including the president, is relatively rare $^{3}$. Only Greece and Poland have implemented such a solution and until recently also the French law provided such a possibility but the amendment of the Constitution in 2007 changed

1 Artigo recebido em 05/10/2017, aprovação comunicada em 10/03/2018.

2 Phd. in Law in Rzeszów University The author is an Associate Professor in Institute of Political Science on the Faculty of Sociology and History of University of Rzeszow in Poland. E-mail: chatazawsia@ wp.pl.

3 As stated by W. Odrowąż - Sypniewski and B. Szepietowska, the system of constitutional responsibility accepted in Poland does not find adequate equivalents in other European countries. However, it would have been tempted to argue that the Greek regulations in this matter could be regarded as close to the Polish rulings. ODROWAZŻ, W; SYPNIEWSKI; SZEPIETOWSKA, B. O systemach odpowiedzialności konstytucyjnej „Ekspertyzy i Opinie Prawne. Biura Studiów i Ekspertyz Kancelarii Sejmu, 2000, no. 3, p. 7. 
the legislation within that scope ${ }^{4}$. The subject of the study is the analysis of Polish regulations concerning the State Tribunal in the context when the National Assembly adopts a resolu-tion to put the President in charge of committing a constitutional delinquency.

Key-words: state tribunal; adjudication; president; constitutional responsibility

\section{INTRODUCTION}

The creation of a special body whose sole purpose is to rule on violations of the constitution or statutes by senior state officials, including the president, is relatively rare $^{5}$. Only Greece and Poland have implemented such a solution and until recently also the French law provided such a possibility but the amendment of the Constitution in 2007 changed the legislation within that scope ${ }^{6}$. The subject of the study is the analysis of Polish regulations concerning the State Tribunal in the context when the National Assembly

4 GDULEWICZ, E. System konstytucyjny Francji. Warszawa, 2000, p. 39; POPŁAWSKA, E. Odpowiedzialność Prezydenta V Republiki Francuskiej. Państwo i Prawo. 1991, no. 11, p. 71 - 80. p. 71 - 80; KUBUJ, K. Francja: Odpowiedzialność karna Prezydenta V Republiki Francuskiej. Przegląd Sejmowy, 2002, no 3, p. 119 - 122; KUBUJ, K. Odpowiedzialność karna Prezydenta V Republiki Francuskiej. Przegląd Sejmowy. 2008, no 6; SKRZYDLO, W. Formy odpowiedzialności konstytucyjnej w Republice Francuskiej. In: GRABOSKA, S; GRABOWSKI, R. Formy odpowiedzialności konstytucyjnej w państwach europejskich, Toruń 2010, p. 139 - 140; SKRZYDŁO, W. Ustrój polityczny Francji. Warszawa 1992, p. 150 - 152; BALICKI, R. Ustroje państw współczesnych. Wrocław 2003, p. 160 - 161; WOJTYCZEK, K. Republika Francuska. In: SARNECKI, P. Ustrój Unii Europejskiej i ustroje państw czlonkowskich. Warszawa 2007, p. 185.

5 As stated by W. Odrowąż - Sypniewski and B. Szepietowska, the system of constitutional responsibility accepted in Poland does not find adequate equivalents in other European countries. However, it would have been tempted to argue that the Greek regulations in this matter could be regarded as close to the Polish rulings. ODROWĄŻ, W; SYPNIEWSKI; SZEPIETOWSKA, B. O systemach odpowiedzialności konstytucyjnej, Ekspertyzy i Opinie Prawne. Biura Studiów i Ekspertyz Kancelarii Sejmu, 2000, no. 3, p. 7.

6 GDULEWICZ, E. System konstytucyjny Francji. Warszawa, 2000, p. 39; POPŁAWSKA, E. Odpowiedzialność Prezydenta V Republiki Francuskiej. Państwo i Prawo. 1991, no. 11, p. 71 - 80; KUBUJ, K. Francja: Odpowiedzialność karna Prezydenta V Republiki Francuskiej. Przegląd Sejmowy, 2002, no 3, p. 119 - 122; KUBUJ, K. Odpowiedzialność karna Prezydenta V Republiki Francuskiej. Przegląd Sejmowy. 2008, no 6; SKRZYDLO, W.Formy odpowiedzialnościkonstytucyjnej w Republice Francuskiej. In: GRABOSKA, S; GRABOWSKI, R. Formy odpowiedzialności konstytucyjnej w państwach europejskich, Toruń 2010, p. 139 - 140; SKRZYDŁO, W. Ustrój polityczny Francji. Warszawa 1992, p. 150 - 152; BALICKI, R. Ustroje państw współczesnych. Wrocław 2003, p. 160 - 161; WOJTYCZEK, K. Republika Francuska. In: SARNECKI, P. Ustrój Unii Europejskiej i ustroje państw czlonkowskich. Warszawa 2007, p. 185. 
adopts a resolution to put the President in charge of committing a constitutional delinquency. The State Tribunal is an organ of judiciary ${ }^{7}$, its organization has been governed by art. 199 of the Polish Constitution and art. 18, 19, 20e of the Act on the State Tribunal. As a judicial body, the Court, in accordance with art. 173 of the Constitution of the Republic of Poland, is separate and independent of other authorities in its activities. The State Court is a court of first instance and a court of second instance ${ }^{9}$. At first instance, the Court is composed of a chairman and four members ${ }^{10}$. In the second instance, the Tribunal is composed of the chairman and six members, excluding the judges who took part in the case at first instance ${ }^{11}$. Apart from the hearing, the State Tribunal has the following composition: a chairman and two members ${ }^{12}$. The activities of the are financed from the budget of the Supreme Court. The Executive Office of the Supreme Court provides secretarial services of the State Tribunal ${ }^{13}$.

7 DUDEK, D. Organy ochrony prawnej. In: SKRZYDŁO, W. Ustrój polityczny i gospodarczy współczesnej Polski. Lublin 1996, p. 155 - 156; LASKOWSKA, M.; SOKOLEWICZ, W. Odpowiedzialność czlonków Rady Ministrów w Konstytucji RP na tle porównawczym. Zeszyty Naukowe Wyższej Szkoły Handlu i Prawa im. Ryszarda Łazarskiego w Warszawie. 2002, no 1, p. 154 - 155; SZUMIŁO - KULCZYCKA, D. Odpowiedzialność karna przed Trybunałem Stanu. Przegląd Sejmowy. 2001, no 4, p. 103.

8 BANASZAK, B. Prawo konstytucyjne. Warszawa 2004, p. 661 - 666; SZYSZKOWSKI, W. Trybunał Stanu. In: WITKOWSKI, Z. Prawo konstytucyjne. Toruń 2000, p. 436 - 438; SKRZYDŁO, W. Ustrój polityczny RP w świetle Konstytucji z 1997 r. Warszawa 2009, p. 219 - 220; DUDEK, D; SOBCZAK, J. Władza sądownicza w Konstytucji RP. In: MOJAK, R. Ustrój konstytucyjny Rzeczypospolitej Polskiej. Lublin 2000, p. 268 - 269.

9 KRAWCZYK, R. P. Dyskusja wokół koncepcji Trybunału Stanu. In: Prawo państwowe. Acta Uniwersitatis Lodziensis. Folia Iuridica 43, Łódź 1989, p. 77 - 97; ZALEŚNY, J. Charakter prawny Trybunału Stanu. Zagadnienia wybrane. Przegląd Sądowy. 2007, no 7 - 8, p. 50 - 57.

10 KEMPISTY, H. Trybunal Stanu. Postępowanie w pierwszej instancji, no. 4, Warszawa 1983, p. 11 - 12; SARNECKI, P. Prezydent Rzeczypospolitej Polskiej. Komentarz do przepisów. Kraków 2000, p. $114-115$.

11 OPALIŃSKI, B. Trybunal Stanu w polskim porządku ustrojowym. Przegląd Prawa Konstytucyjnego. Wladza sądownicza w państwach europejskich. 2011, no 2, p. 113 - 114.

12 ZIĘBA - ZAŁUCKA, H. Formy odpowiedzialności konstytucyjnej w Rzeczypospolitej Polskiej, In: GRABOSKA, S; GRABOWSKI, R. Formy odpowiedzialności konstytucyjnej w państwach europejskich, Toruń 2010, p. 237; PIETRZAK, M. Odpowiedzialność konstytucyjna w Polskiej Rzeczypospolitej Ludowej i w III Rzeczypospolitej. In: IWANICKA, K; SKOWRONEK, M; STEMBROWICZ, K. Parlament, prawo, ludzie. Studia ofiarowane profesorowi Juliuszowi Bardachowi w sześćdziesięciolecie pracy twórczej. Warszawa 1996, p. 202 - 203.

$13 \S 10$ uchwały Sejmu Polskiej Rzeczypospolitej Ludowej z dnia 6 lipca 1982 r. w sprawie regulaminu czynności Trybunału Stanu (M.P. Nr 17, poz. 135). 
I.

According to art. 199 of the Constitution of the Republic of Poland, the State Tribunal consists of a chairman, two deputies and sixteen members elected by the Sejm from among the deputies and senators for the duration of their term. After the end of the term of office, the State Tribunal retains its powers until a new composition is selected. The deputy chairman of the Tribunal and at least half of the members of the State Tribunal should have the qualifications required for the position of a judge ${ }^{14}$. Members of the Tribunal may only be Polish nationals who exercise full public rights, are not remanded and are not employed by the bodies of the government. In the exercise of the function of a judge of the State Tribunal, they are independent and subordinate only to the Constitution and the statutes. People selected to become members of the Tribunal make a solemn pledge of judges before the Marshal of the Sejm. Neither the Constitution nor the Act regulate the number of terms, thereby it is allowed for a person to be re-elected as a member of the Tribunal ${ }^{15}$. The members of the Tribunal are elected at the first sitting of the newly elected Sejm. The Act on the State Tribunal does not regulate the mode of electing members of the Tribunal. These matters are ruled by the Sejm's regulations. According to them, the selection of members of the State Tribunal takes place jointly, unless the Sejm decides otherwise. The right to nominate candidates for members of the Tribunal, in accordance with art. 30 of the Sejm's regulations, is held by: the Marshal of the Sejm or a group of at least 35 deputies. The deadline for submission of applications is set by the Marshal of the Sejm on the first day of the first sitting of the Sejm. Members are elected by an absolute majority of votes ${ }^{16}$. A member of the State Tribunal holds a judicial immunity and is entitled to personal immunity. The Immunity of a Member of the Tribunal is governed by art. 200 of the Constitution of the Republic of Poland, art. 15a on the State Tribunal Act and the law on the on the Common Court System. The scope of the immunity is the same as for judges ${ }^{17}$.

14 SOBCZAK, J. Sądy i trybunały. In: SKRZYDŁO, W. Polskie prawo konstytucyjne, Lublin 2005, p. 416.

15 KUCIŃSKI, J. Konstytucyjny ustrój państwowy Rzeczypospolitej Polskiej, Warszawa 2003, p. 337 - 338; SKŁADOWSKI, K. Trybunał Staniu. In: GÓRECKI, D. Polskie prawo konstytucyjne. Warszawa 2008, p. 226 - 227.

16 KRĘCISZ, W. Władza sądownicza - trybunały. In: GDULEWICZ, E. Konstytucyjny system organów państwowych. Lublin 2009, p. $250-251$.

17 SKRZYDŁO, W. Konstytucja Rzeczypospolitej Polskiej. Komentarz. Warszawa 2007, p. 211 212. 
Emptying a position of a member of the State Tribunal results from a waiver of a function, a permanent loss of capacity to perform activities, or a final court judgment. The Marshal of the Sejm, by way of order, declares the vacant position of a member of the Tribunal, while informing the Sejm of this fact. Should the mandate of a Member of the State Tribunal expire, the Sejm shall make a supplementary selection. In this case, the supplementary selection shall be made separately for each emptied position ${ }^{18}$.

The function of the President of the State Tribunal is held by the First President of the Supreme Court. The scope of his duties and powers is governed by art. 15a of the State Tribunal Act and the resolution of the Sejm of 6 July 1982 on the Rules of Procedure of the State Tribunal ${ }^{19}$.

The President of the State Tribunal directs all the work of the Tribuna ${ }^{20}{ }^{2}$. He designates the panel at first instance, in addition to the main proceedings and the chairmen of these compositions, as well as the members of the rapporteurs and the secretary. The President issues matters to the meetings and hearings, determines their daily appointments and sets the agenda as well as issues orders outside the hearing and handles the correspondence of the Tribunal. In addition, he transmits the judgments of the State Tribunal for execution and supervises their execution by public authorities. The President of the State Tribunal has the same powers and duties as the President of the Court and the Chair of the Department in accordance with the Code of Criminal Procedure ${ }^{21}$.

II.

Proceedings before the State Tribunal, that is, adjudication on constitutional responsibility, are determined by several rules of this procedure. Because of the complementary role of criminal law, they are primarily derived from the law and criminal law ${ }^{22}$, though not only

18 NALEZIŃSKI, B. Organy władzy sądowniczej. In: SARNECKI, P. Prawo konstytucyjne. RP, Warszawa 2011, p. 422 - 424.

19 GARLICKI, L. Polskie prawo konstytucyjne. Zarys wykładu. Warszawa 2010, p. 385 - 386.

$20 \S 2$ reg. of Trybunal of State.

21 BANASZAK, B. Trybunal Stanu - stagnacja czy zmiany? Zeszyty Naukowe Sądownictwa Administracyjnego. 2008, no 1, p. 9 - 22; KOZIK, M. Trybunał Stanu - żywa instytucja czy martwy przepis? Studia Iuridica Lubliniensia. T. V, Lublin 2005, p. 109 - 126.

22 MAREK, A. Pojęcie zasady procesu karnego.Państwo i Prawo. 1970, no. 3 - 4. In: ARTYMIAK, G; ROGALSKI, M; SOBOLEWSKI, Z. Proces karny. Część ogólna. Warszawa 2007, p. 32; CIEŚLAK, 
because some of them come from the state and legal theory ${ }^{23}$. The principle of material truth is of fundamental importance, and the principles of openness, collegiality, instinctiveness, adversarial, fiduciary and loyalty are also of great importance. They concern the form and manner of conduct of the State Tribunal. On the other hand, the principles of presumption of innocence and of the rights of defence govern the legal situation of the person drawn to constitutional responsibility. The last group - including rules: free assessment of evidence and directness - serves to regulate evidence ${ }^{24}$.

Proceedings before the Tribunal apply those provisions of the criminal procedure that do not conflict with the State Tribunal Act and are compatible with the specificity of proceedings on constitutional responsibility ${ }^{25}$.

The Tribunal, when preparing for the main hearing, carries out a preliminary inspection of the resolution of the National Assembly, which is an indictment of the President for committing a constitutional delict. Such a review consists of a study of admissibility of the process and formal preparation of the complain ${ }^{26}$. However, according to art. $20 \mathrm{sec}$. 3 of the State Tribunal Act, the indictment cannot be returned to the National Assembly to supplement or extend the proceedings. Actions taken in preparation for the main hearing may be initiated by the State Tribunal or at the request of any of the parties to the proceedings, except that the Tribunal is not bound by the request of the party ${ }^{27}$. If the case is considered by the State Tribunaland a legal matter arises which requires a substantive interpretation of the law, the Tribunal may defer the resolution of the case and refer the matter to be settled by the full panel of the State Tribunal.

M. Zasady procesu karnego i ich system. Zeszytu Naukowe Uniwersytetu Jagiellońskiego. Prawo, 1956, no 3, p. 158.

23 WRONKOWSKA, S; ZIELIŃSKI, M; ZIEMBIŃSKI, Z. Zasady prawa. Zagadnienia podstawowe, Warszawa 1974.

24 ZALEŚNY, J. Odpowiedzialność konstytucyjna w prawie polskim okresu transformacji ustrojowej. Toruń 2004, p. 246 - 262.

25 KEMPISTY, H. Trybunal Stanu. Postępowanie w pierwszej instancji, no. 4, Warszawa 1983, p. 10 $-18$.

26 ZALEŚNY, J. Odpowiedzialność konstytucyjna w prawie polskim okresu transformacji ustrojowej. Toruń 2004, p. 263 - 269.

27 ŚWIDA, Z. Łagiewska, Przebieg postępowania dotyczącego odpowiedzialności konstytucyjnej, In: ŚWIDA, Z. Łagiewska, Trybunał Stanu w PRL, Warszawa 1983, p. 202. 
The case is investigated within the limits of the indictment ${ }^{28}$. The accuser cannot accuse the accused of committing other acts than those included in the prosecution. Proceedings before the State Tribunal require the participation of an attorney. Proceedings are governed by the provisions of the State Court Act and the Criminal Procedure Code respectively. The accused, the witnesses and the experts are exempted from the duty of state and official secrecy. The exclusion of the publicity of the hearing before the Tribunal can be justifiedonly by the consideration of state security or state secrets ${ }^{29}$.

If the indictment meets the formal requirements, the case is referred to the main hearing and becomes subject to proceedings before the State Tribunal ${ }^{30}$. The hearing is governed by the President of the State Tribunal in writing. The order includes: the names of the members of the Tribunal in which the panel is sitting, the date, time and place of the hearing, the parties and other persons to be present at the hearing, and the persons who should be notified of the date and other necessary preparation of the hearing ${ }^{31}$. After initiating the main hearing there is no possibility to change the composition of the adjudication.

The main hearing can be divided into several stages: commencement, court proceedings, votes of the parties and the verdict ${ }^{32}$. The hearing starts with the verification of the people who have been summoned and also whether there is no obstruction to the case. The next stage is thecourt proceedings that consists of reading the indictment, the hearing of the President, further evidence ${ }^{33}$ and closing the court proceedings. During the court proceedings, the President gives explanations, witnesses are interviewed, experts are interviewed. At the same time, all documents are also being read- both official and private - that are relevant to the case. The last part of the hearing is the judgment, involving the deliberation of members of the Court of Justice over the sentence, the vote on the verdict, and the preparation of the judgment in writing. These actions take place in camera. As in the criminal process, in

28 PIASECKI, K. Organizacja wymiaru sprawiedliwości w Polsce. Warszawa 2005, p. 163.

29 Art. 18 of Act of Trybunal of State.

30 SARNECKI, P. Opinia w sprawie odpowiedzialności konstytucyjnej. Jak należy rozumieć zwrot sprawy będące przedmiotem postępowania [...] przed [...] Trybunałem Stanu. (art. 241 ust. 1 Konstytucji)Przegląd Sejmowy. 2000, no 5, p. 51 - 52.

31 ZALEŚNY, J. Odpowiedzialność konstytucyjna w prawie polskim okresu transformacji ustrojowej. Toruń 2004, p. 268.

32 KALINOWSKI, S. Rozprawa główna w polskim prawie karnym. Warszawa 1975, p. 66.

33 CZUBALSKI, M. O pojęciu i klasyfikacji środków dowodowych. Państwo i Prawo. 1968, no. 1. 
the process of holding the President in charge of constitutional responsibility, a member of the adjudicating panel may, by signing a judgment in the case, file a separate sentence concerning all or a part of the judgment or its justification ${ }^{34}$.

The next stages of the hearing are the public announcement of the judgment, the oral justification thereof and informing the parties about the law, the time and the form of appeal. They are held openly unless all or part of the hearing has been classified as confidential.

By ruling at first instance, the State Tribunal can issue the following judgments: a conviction, an acquittal, termination or conditional termination of the proceedings. If the Tribunal states that the President has not committed a constitutional delinquency or if there is no sufficient evidence or the act committed is not classified as a constitutional delict, it shall deliver an acquittal ${ }^{35}$.

The State Tribunal terminates the proceedings when it finds that the President has died, the limitation period has expired, or the proceedings on the same constitutional delinquency of the President have been legally completed or are already pending or the indictment has been made by an unauthorized body or the President at the moment committing the constitutional delict was in a state deviating from normal (mental illness, mental retardation). Termination or conditional termination of proceedings before the Tribunal can only be performed at a hearing.

If, in the course of proceedings, the Tribunal deems the appropriateness of accusing the President of committing a constitutional delinquency, it shall convict.

Polish regulations governing the constitutional responsibility of the President allow the possibility of appealing against a judgment at first instance, which corresponds to the principle of two-instance court proceedings ${ }^{36}$. Each party to the proceedings may appeal the judgment of the State Tribunal in whole or in part, or the justification thereof. ${ }^{37}$. The appeal period runs separately for each eligible person and is 30 days from the date of delivery

34 KEMPISTY, Z. Votum separatum. Państwo i Prawo. S.1. 1963, no. 2; BRATOSZEWSKI, J. Zdanie odrębne w procesie karnym. Warszawa 1973; LIPCZYŃSKI, M. Votum separatum we współczesnym polskim ustawodawstwie karnoprocesowym oraz w praktyce. In: FIEMA, J; GUTEKUNST, W; HUBERT, S. Studia Prawnicze. Księga Pamiątkowa ku czci prof. dra Witolda Świdy, Warszawa 1969.

35 GARLICKI, L. Polskie prawo konstytucyjne. Zarys wykładu. Warszawa 2010, p. 392.

36 Art. 78 Constitution of Poland.

37 PIETRZAK, M. Odpowiedzialność konstytucyjna w Polsce,Warszawa. 1992, p. 125. 
of the copy of the judgment with justification. In the second instance, the Court has the following composition: a chairman and six members, excluding the judges who took part in the case at first instance. No judgment of the State Tribunal issued in the second instance is available for cassation.

Appeal proceedings consist of the following parts: actions of the Court of First Instance in connection with filing an appeal, preparation for appeal proceedings, appeal proceedings, final actions. By ruling in the second instance, the tribunal repeals or changes the judgments given at first instance, if the relative cause of the appeal is found. This may be due to: blatant inconsistency of the case or improper use of the preventive measure, error in the findings of fact, if they could affect the judgment. Other causes are the offense of the rules of conduct if they could have affected the judgment or offense of substantive law ${ }^{38}$.

In addition, the State Tribunal, in its second instance, is required to examine whether there was no absolute cause of appeal in the proceeding ${ }^{39}$. If this is the case, the State Tribunal repeals the contested judgment. Such reasons include: participation in the conviction of a person who is not authorized, unable or excluded by law; improper composition of the State Tribunal; absence of any member of the State Tribunal at all hearings; adjudicating the State Tribunal on matters not belonging to its jurisdiction; breach of the rule of voting by majority vote; not to admit the judgment delivered by any member of the State Tribunal; enforceable ruling contradiction in its content; issuing a judgment in a case that has already been legally completed; occurrence of exclusion from proceedings; lack of defender or lack of participation of the defender of the President in all actions during the proceedings; recognition of the case without fulfilling the duty of the Presidency as a person drawn to constitutional responsibility. In the last three cases, the sentence can only be performed in favour of the defendant for committing a constitutional delict ${ }^{40}$.

38 ZABŁOCKI, S. Postępowanie odwoławcze, kasacyjne i wznowieniowe w procesie karnym. Warszawa 1999, p. 90 - 99; KOTOWSKI, S. Trybunal Stanu. Postępowanie odwolawcze. no. 8, Warszawa 1983, p. 3 - 22.

39 KOTOWSKI, S. Trybunal Stanu. Postępowanie odwoławcze. no. 8, Warszawa 1983, p. 10.

40 ZALEŚNY, J. Odpowiedzialność konstytucyjna w prawie polskim okresu transformacji ustrojowej. Toruń 2004, p. 279. 


\section{III.}

At the end of the hearing before the State Tribunal and the President's recognition of the guilty party's perpetration of constitutional delicts, the authority shall proceed to punish. According to art. $25 \mathrm{sec} .3$ of the State Tribunal Act, if the President is found guilty of at least unintentional committal of the charges against him, the State Tribunal shall adjudicate his decision ex officio ${ }^{41}$. The court may only adjudge the defendant's guilt, without punishment, because of the negligible degree of social harm of the offense or the particular circumstances of the case ${ }^{42}$. On the other hand, according to art. 23, 25 and 26 of the State Tribunal Act, for acts belonging to a constitutional delinquency, if they do not fulfil the character of a crime or a fiscal offense, the State Tribunal shall summarily or severally impose the following penalties: the loss of active and passive electoral rights in elections to the office of the President, the Sejm and to Senat, to the European Parliament and to local and regional authorities, banning the holding of managerial posts or positions of special responsibility in state organs and social organizations, and the loss of all or some of the orders, decorations and honorary titles. These penalties can be imposed for a period of two to ten years ${ }^{43}$. The presidency's delimitation period is ten years after the commission of the act ${ }^{44}$. The fact that the offender no longer holds office or does not hold office does not preclude the initiation and conduct of proceedings ${ }^{45}$.

After the end of the hearing and the judgment on the constitutional delict by the President of the Republic of Poland, the President of the State Tribunal is responsible for executing

41 SZYSZKOWSKI, W. Trybunał Stanu. In: WITKOWSKI, Z. Prawo konstytucyjne. Toruń 2000, p. 438 - 439, KRĘCISZ, W. Władza sądownicza - trybunały. In: GDULEWICZ, E. Konstytucyjny system organów państwowych. Lublin 2009, p. 257.

42 Art. 25 sec. 4 Act of Tribunal of State. SOBCZAK, J. Sądy i trybunały. In: SKRZYDŁO, W. Polskie prawo konstytucyjne, Lublin 2005, p. 418 - 419; NALEZIŃSKI, B. Organy władzy sądowniczej. In: SARNECKI, P. Prawo konstytucyjne. RP, Warszawa 2011, p. 435.

43 RYBICKI, M. Trybunał Konstytucyjny, Trybunał Stanu, Najwyższa Izba Kontroli. In: FUKS, T; ŁOPATKA, A; RYBICKI, M; SKRZYDŁO, W. Ustrój polityczny Rzeczypospolitej Ludowej, Warszawa 1986, p. 184.

44 GARLICKI, L. Polskie prawo konstytucyjne. Zarys wykladu. Warszawa 2010, p. 392; SKŁADOWSKI, K. Trybunał Staniu. In: GÓRECKI, D. Polskie prawo konstytucyjne. Warszawa 2008, p. 230.

45 SKRZYDŁO, W. Ustrój polityczny RP w świetle Konstytucji z 1997 r. Warszawa 2009, p. 220. 
the judgment ${ }^{46}$. For this purpose, he directs the judgment to be executed by the District Court in Warsaw ${ }^{47}$.

IV.

Polish constitutional traditions, like the constitutional traditions of most European countries, do not provide for the election of the deputy president or vice president. The replacement of the President, until the end of the proceedings on constitutional responsibility falls on the President of the Chamber of Deputies. In the case of an ex officio in connection with a constitutional delict, it is necessary to manage the early elections for the presidency.

Adoption of the resolution to bring the President into the state of indictment according to art. $145 \mathrm{sec} .3$ of the Constitution of the Republic of Poland and art. $11 \mathrm{sec} .1$ of the State Tribunal Act results in suspension in office ${ }^{48}$. During the suspension of the President, his duties are carried out by the Marshal of the Sejm and in the situation when he cannot perform thereof, the Marshal of the Senate ${ }^{49}$. The Marshal of the Sejm performs the duties of the President of the Republic of Poland personally, joining them with the function of the Marshalso. The legislator recognizes that the Marshal of the Sejm or the Senate bears responsibility for exercising constitutional responsibility under conditions and in the manner identical to that of the head of state ${ }^{51}$. The doctrine presents a view that such extension of the responsibility of the Marshal for acts that fall within the scope of substitution is legally superfluous and may, at least in part, be unacceptable $\mathrm{e}^{52}$ and that there is no explicit support

46 BANASZAK, B. Prawo konstytucyjne. Warszawa 2004, p. 666.

$47 \S 5$ reg. of Tribunal of State.

48 GARLICKI, L. Polskie prawo konstytucyjne. Zarys wykładu. Warszawa 2010, p. 391.

49 Art. 131 Constitution of Poland.

50 POPŁAWSKA, E. Opróżnienie urzędu Prezydenta. In: SKRZYDŁO, W; GRABOWSKA, S.; GRABOWSKI, R. Konstytucja Rzeczypospolitej Polskiej. Komentarz encyklopedyczny, Warszawa 2009, p. 315 - 317; KRUK, M. Wykonywanie obowiązków prezydenta RP. In: SKRZYDŁO, W; GRABOWSKA, S.; GRABOWSKI, R. Konstytucja Rzeczypospolitej Polskiej. Komentarz encyklopedyczny, Warszawa 2009, p. 687 - 688.

51 Art. 2 sec. 3 Act of Tribunal of State.

52 ZUBIK, M. Trybunał Stanu - stan Trybunału (Słów kilka o polskim sądzie nad notablami). In: SZMYT, A. Trzecia wladza. Sądy i Trybunały w Polsce. Materiały Jubileuszowego L Ogólnopolskiego Zjazdu Katedr i Zakładów Prawa Konstytucyjnego. Gdynia, 24 - 26 kwietnia 2008r., Gdańsk 2008, p. 45; ZIĘBA - ZAŁUCKA, H. Formy odpowiedzialności konstytucyjnej w Rzeczypospolitej Polskiej, In: GRABOSKA, S; GRABOWSKI, R. Formy odpowiedzialności konstytucyjnej w państwach 
in art. 198 and $131 \mathrm{sec} .2$ of the Constitution ${ }^{53}$. However, much of the doctrine ${ }^{54}$ using both systemic and historical interpretation, recognizes that legitimate entities in a similar state should be treated similarly in a legal state (art. 2 of the Constitution) ${ }^{55}$. It can therefore be assumed that the person who replaces the President in the performance of his duties should be subject to the same constitutional responsibility ${ }^{56}$. Where the State Tribunal determines the validity of the charges submitted to the President in the indictment, the duties of the President are being performed by the Marshal of the Sejm or of the Senate until thenewly elected President takes office.

The substantive scope of the duties performed by the Marshal of the Sejm (or the Mar-shal of the Senate) fulfilling the duties of the President coincides with all duties of the President of the Republic. There is only one exception - the Constitution of the Republic of Poland states that persons performing the duties of the President of the Republic of Poland, ie. the Marshal of the Sejm or Marshal of the Senate, cannot take a decision on shortening the term of the Sejm (art. $131 \mathrm{sec} .4$ of the Constitution of the Republic of Poland). They cannot do this even when constitutional grounds authorizing or requiring shortening of the term of office. This provision, as noted by M. Kruk, protects state power from breaking its continuity and - especially - the situation when the office of the President of Poland will

europejskich, Toruń 2010, p. 225.

53 GARLICKI, L. Polskie prawo konstytucyjne. Zarys wykładu. Warszawa 2010, p. 386.

54 GROSZYK, H. Uwagi o potrzebie i kierunkach zmian ustawowej regulacji Trybunału Stanu (w związku z art. 236 ust. 1 Konstytucyjni RP. In: DĘBOWSKA-ROMANOWSKA, T; JANKIEWICZ, A. Konstytucja, ustrój, system finansowania państwa. Księga pamiątkowa ku czci prof. Natalii Gajl, Warszawa 1999, p. 72.

55 ZALEŚNY, J. Odpowiedzialność konstytucyjna w prawie polskim okresu transformacji ustrojowej. Toruń 2004, p. 174; SZYSZKOWSKI, W. Trybunał Stanu. In: WITKOWSKI, Z. Prawo konstytucyjne. Toruń 2000, p. 436, BIEŃ, A. Kacała, Kilka uwag w kwestii odpowiedzialności Prezydenta RP przed Trybunałem Stanu. In: Podmioty administracji publicznej i prawne formy ich działania: studia i materiały z Konferencji Naukowej poświęconej Jubileuszowi 80 - tych urodzin Profesora Eugeniusza Ochendowskiego. Toruń, 15 - 16 listopada 2005, p. 47 - 48; KRĘCISZ, W. Władza sądownicza - trybunały. In: GDULEWICZ, E. Konstytucyjny system organów państwowych. Lublin 2009, p. 252.

56 GRAJEWSKI, J. Warunki ustawowe i wymogi formalne wstępnego wniosku o pociągnięcie do odpowiedzialności konstytucyjnej przed Trybunałem Stanu. Przegląd Sejmowy. 2003, no 1, p. 11; BANASZAK, B. Prawo konstytucyjne. Warszawa 2004, p. 628; GROSZYK, H. Uwagi o potrzebie i kierunkach zmian ustawowej regulacji Trybunału Stanu (w związku z art. 236 ust. 1 Konstytucyjni RP. In: DĘBOWSKA-ROMANOWSKA, T; JANKIEWICZ, A. Konstytucja, ustrój, system finansowania państwa. Księga pamiątkowa ku czci prof. Natalii Gajl, Warszawa 1999, p. 72; GARLICKI, L. Polskie prawo konstytucyjne. Zarys wykładu. Warszawa 2010, p. 386. 
function as an alternate, while being temporarily a parliamentary, during the electoral period ${ }^{57}$. The same is true of the President of the Republic of Poland, but the scope and nature of the powers delegated by the Marshal of the Sejm. It also includes the requirement to act upon the request and the requirement to counter the signatures of the President of the Republic of Poland by the President of the Council of Ministers for their validity ${ }^{58}$.

V.

If the President of the Republic of Poland is ex officio dismissed by a court of competent jurisdiction, the Marshal of the Sejm shall immediately order the election of the President of the Republic. The Marshal of the Sejm manages the election for the day no later than the fourteenth day after the office was vacated, setting the date of the election for a day off work within sixty days of the day of the election ${ }^{59}$. The Marshal of the Sejm, according to art. 290 of the electoral code, governs the election of the President of the Republic by way of a resolution. The order of the Marshal of the Sejm shall be made public and published in the Journal of Laws of the Republic of Poland no later than 3 days after the date of the election order.

\section{CONLUSION}

The analysis of the rules governing the proceedings before the State Tribunal on the conduct of the President's prosecution for constitutional delinquency ${ }^{60}$ has led to several conclusions.

57 KRUK, M. Wykonywanie obowiązków prezydenta RP. In: SKRZYDŁO, W; GRABOWSKA, S.; GRABOWSKI, R. Konstytucja Rzeczypospolitej Polskiej. Komentarz encyklopedyczny, Warszawa 2009, p. 688.

58 POPŁAWSKA, E. Opróżnienie urzędu Prezydenta. In: SKRZYDŁO, W; GRABOWSKA, S.; GRABOWSKI, R. Konstytucja Rzeczypospolitej Polskiej. Komentarz encyklopedyczny, Warszawa 2009, p. 317.

59 Art. 128 sec. 2 Constitution of Poland, art. 289 sec. 2 of Act of Electoral Code 5.01.2011, (Dz. U. Nr 21, poz. 112)

60 SOKOLEWICZ, W. Konstytucyjna regulacja władzy sądowniczej. In: DĘBOWSKAROMANOWSKA, T; JANKIEWICZ, A. Konstytucja, ustrój, system finansowania państwa. Księga pamiątkowa ku czci prof. Natalii Gajl, Warszawa 1999, p. 194 - 196; GARLICKI, L. Charakter ustrojowy nowych trybunałów. Państwo i Prawo. 1983, z. 1, p. 28 - 29. 
Failure to comply with the rules of the deadline may result in the extension of the procedure. As a model, Greek regulations can be mentioned which set strict deadlines for carrying out individual activities related to the President's taking responsibility for committing a constitutional delict ${ }^{61}$.

The composition of the State Tribunal requires the qualifications essential for the function of a judge only in the case of half of the Tribunal and of the deputies of the President. It is problematic to use the term "should" in art. $199 \mathrm{sec} .1$ of the Constitution of the Republic of Poland, because it does not result from the absolute obligation to have the qualifications of judges, but only because such persons may have judicial powers but do not have to. In my view, the best solution would be to clarify the rules governing the composition of the State Tribunal so that half of its members would need to have judicial powers and the rest could have documented their legal experience or a degree or a scientific title in legal science.

Provisions do not allow the National Assembly to return a resolution being an indictment in order to supplement deficiencies or remove errors disclosed during the initial screening of a resolution. It is also impossible to remove these shortcomings by the State Tribunal. This may cause problems in further processing.

The regulation of the President's replacement, when the parliament adopted a resolution to draw him into constitutional responsibility, resulting in the President being suspended in office, seems to be better. The person who replaces the President is subject to constitutional responsibility on the same grounds as the President, which is appropriate, due to the scope of duties and powers. Similarly to the President, the person substituting him may commit a constitutional offense and should therefore be subject to full constitutional responsibility.

\section{REFERENCES}

BALICKI, R. Ustroje państw współczesnych. Wrocław 2003.

BANASZAK, B. Prawo konstytucyjne. Warszawa 2004.

BANASZAK, B. Trybunal Stanu - stagnacja czy zmiany? Zeszyty Naukowe Sądownictwa Administracyjnego. 2008, no 1, p. 9 - 22,

61 GRABOWSKA, S. Odpowiedzialność konstytucyjna Prezydenta Grecji. Przegląd Sejmowy. 2012, no 5, p. 215-226. 
BIEŃ, A. Kacała, Kilka uwag w kwestii odpowiedzialności Prezydenta RP przed Trybunałem Stanu. In: Podmioty administracji publicznej i prawne formy ich dzialania: studia i materiały z Konferencji Naukowej poświęconej Jubileuszowi 80 - tych urodzin Profesora Eugeniusza Ochendowskiego. Toruń, 15 - 16 listopada 2005.

BRATOSZEWSKI, J. Zdanie odrębne w procesie karnym. Warszawa 1973.

CIEŚLAK, M. Zasady procesu karnego i ich system. Zeszytu Naukowe Uniwersytetu Jagiellońskiego. Prawo, 1956, no 3.

CZUBALSKI, M. O pojęciu i klasyfikacji środków dowodowych. Państwo i Prawo. 1968, no. 1.

DUDEK, D. Organy ochrony prawnej. In: SKRZYDŁO, W. Ustrój polityczny i gospodarczy współczesnej Polski. Lublin 1996.

DUDEK, D; SOBCZAK, J. Władza sądownicza w Konstytucji RP. In: MOJAK, R. Ustrój konstytucyjny Rzeczypospolitej Polskiej. Lublin 2000.

GARLICKI, L. Charakter ustrojowy nowych trybunałów. Państwo i Prawo. 1983, z. 1. GARLICKI, L. Polskie prawo konstytucyjne. Zarys wykladu. Warszawa 2010.

GDULEWICZ, E. System konstytucyjny Francji. Warszawa, 2000.

GRABOWSKA, S. Odpowiedzialność konstytucyjna Prezydenta Grecji. Przegląd Sejmowy. 2012, no 5, p. 215-226.

GRAJEWSKI, J. Warunki ustawowe i wymogi formalne wstępnego wniosku o pociągnięcie do odpowiedzialności konstytucyjnej przed Trybunałem Stanu. Przegląd Sejmowy. 2003, no 1 .

GROSZYK, H. Uwagi o potrzebie i kierunkach zmian ustawowej regulacji Trybunału Stanu (w związku z art. 236 ust. 1 Konstytucyjni RP. In: DĘBOWSKA-ROMANOWSKA, T; JANKIEWICZ, A. Konstytucja, ustrój, system finansowania państwa. Księga pamiątkowa ku czci prof. Natalii Gajl, Warszawa 1999.

KALINOWSKI, S. Rozprawa główna w polskim prawie karnym. Warszawa 1975. 
KEMPISTY, H. Trybunal Stanu. Postępowanie w pierwszej instancji, no. 4, Warszawa 1983.

KEMPISTY, Z. Votum separatum. Państwo i Prawo. S.1. 1963, no. 2.

KOTOWSKI, S. Trybunał Stanu. Postępowanie odwoławcze. no. 8, Warszawa 1983, p. $3-22$.

KOZIK, M. Trybunał Stanu - żywa instytucja czy martwy przepis? Studia Iuridica Lubliniensia. T. V, Lublin 2005, p. 109 - 126.

KRAWCZYK, R. P. Dyskusja wokół koncepcji Trybunału Stanu. In: Prawo państwowe. Acta Uniwersitatis Lodziensis. Folia Iuridica 43, Łódź 1989, p. 77 - 97.

KRĘCISZ, W. Władza sądownicza - trybunały. In: GDULEWICZ, E. Konstytucyjny system organów państwowych. Lublin 2009.

KRUK, M. Wykonywanie obowiązków prezydenta RP. In: SKRZYDŁO, W; GRABOWSKA, S.; GRABOWSKI, R. Konstytucja Rzeczypospolitej Polskiej. Komentarz encyklopedyczny, Warszawa 2009.

KUBUJ, K. Francja: Odpowiedzialność karna Prezydenta V Republiki Francuskiej. Przegląd Sejmowy, 2002, no 3, p. 119 - 122.

KUBUJ, K. Odpowiedzialność karna Prezydenta V Republiki Francuskiej. Przegląd Sejmowy. 2008, no 6.

KUCIŃSKI, J. Konstytucyjny ustrój państwowy Rzeczypospolitej Polskiej, Warszawa 2003.

LASKOWSKA, M.; SOKOLEWICZ, W. Odpowiedzialność czlonków Rady Ministrów w Konstytucji RP na tle porównawczym. Zeszyty Naukowe Wyższej Szkoły Handlu i Prawa im. Ryszarda Łazarskiego w Warszawie. 2002, no 1.

LIPCZYŃSKI, M. Votum separatum we współczesnym polskim ustawodawstwie karnoprocesowym oraz w praktyce. In: FIEMA, J; GUTEKUNST, W; HUBERT, S. Studia Prawnicze. Księga Pamiątkowa ku czci prof. dra Witolda Świdy, Warszawa 1969.

MAREK, A. Pojęcie zasady procesu karnego.Państwo i Prawo. 1970, no. 3 - 4. In: ARTYMIAK, G; ROGALSKI, M; SOBOLEWSKI, Z. Proces karny. Część ogólna. Warszawa 2007. 
NALEZIŃSKI, B. Organy władzy sądowniczej. In: SARNECKI, P. Prawo konstytucyjne. RP, Warszawa 2011.

ODROWĄŻ, W; SYPNIEWSKI; SZEPIETOWSKA, B. O systemach odpowiedzialności konstytucyjnej, Ekspertyzy i Opinie Prawne. Biura Studiów i Ekspertyz Kancelarii Sejmu, 2000, no. 3 .

OPALIŃSKI, B. Trybunał Stanu w polskim porządku ustrojowym. Przegląd Prawa Konstytucyjnego. Władza sądownicza w państwach europejskich. 2011, no 2.

PIASECKI, K. Organizacja wymiaru sprawiedliwości w Polsce. Warszawa 2005.

PIETRZAK, M. Odpowiedzialność konstytucyjna w Polskiej Rzeczypospolitej Ludowej i w III Rzeczypospolitej. In: IWANICKA, K; SKOWRONEK, M; STEMBROWICZ, K. Parlament, prawo, ludzie. Studia ofiarowane profesorowi Juliuszowi Bardachowi w sześćdziesięciolecie pracy twórczej. Warszawa 1996.

PIETRZAK, M. Odpowiedzialność konstytucyjna w Polsce,Warszawa. 1992.

POPŁAWSKA, E. Odpowiedzialność Prezydenta V Republiki Francuskiej. Państwo i Prawo. 1991, no. 11, p. $71-80$.

POPŁAWSKA, E. Opróżnienie urzędu Prezydenta. In: SKRZYDŁO, W; GRABOWSKA, S.; GRABOWSKI, R. Konstytucja Rzeczypospolitej Polskiej. Komentarz encyklopedyczny, Warszawa 2009.

RYBICKI, M. Trybunał Konstytucyjny, Trybunał Stanu, Najwyższa Izba Kontroli. In: FUKS, T; ŁOPATKA, A; RYBICKI, M; SKRZYDŁO, W. Ustrój polityczny Rzeczypospolitej Ludowej, Warszawa 1986.

SARNECKI, P. Opinia w sprawie odpowiedzialności konstytucyjnej. Jak należy rozumieć zwrot sprawy będące przedmiotem postępowania [...] przed [...] Trybunałem Stanu. (art. 241 ust. 1 Konstytucji)Przegląd Sejmowy. 2000, no 5.

SARNECKI, P. Prezydent Rzeczypospolitej Polskiej. Komentarz do przepisów. Kraków 2000 .

SKŁADOWSKI, K. Trybunał Staniu. In: GÓRECKI, D. Polskie prawo konstytucyjne. Warszawa 2008. 
SKRZYDŁO, W. Formy odpowiedzialności konstytucyjnej w Republice Francuskiej. In: GRABOSKA, S; GRABOWSKI, R. Formy odpowiedzialności konstytucyjnej w państwach europejskich, Toruń 2010.

SKRZYDŁO, W. Konstytucja Rzeczypospolitej Polskiej. Komentarz. Warszawa 2007. SKRZYDŁO, W. Ustrój polityczny Francji. Warszawa 1992.

SKRZYDŁO, W. Ustrój polityczny RP w świetle Konstytucji z 1997 r. Warszawa 2009. SOBCZAK, J. Sądy i trybunały. In: SKRZYDŁO, W. Polskie prawo konstytucyjne, Lublin 2005 .

SOKOLEWICZ, W. Konstytucyjna regulacja władzy sądowniczej. In: DĘBOWSKAROMANOWSKA, T; JANKIEWICZ, A. Konstytucja, ustrój, system finansowania państwa. Księga pamiątkowa ku czci prof. Natalii Gajl, Warszawa 1999.

ŚWIDA, Z. Łagiewska, Przebieg postępowania dotyczącego odpowiedzialności konstytucyjnej, In: ŚWIDA, Z. Łagiewska, Trybunal Stanu w PRL, Warszawa 1983.

SZUMIŁO - KULCZYCKA, D. Odpowiedzialność karna przed Trybunałem Stanu. Przegląd Sejmowy. 2001, no 4.

SZYSZKOWSKI, W. Trybunał Stanu. In: WITKOWSKI, Z. Prawo konstytucyjne. Toruń 2000 .

WOJTYCZEK, K. Republika Francuska. In: SARNECKI, P. Ustrój Unii Europejskiej i ustroje państw członkowskich. Warszawa 2007.

WRONKOWSKA, S; ZIELIŃSKI, M; ZIEMBIŃSKI, Z. Zasady prawa. Zagadnienia podstawowe, Warszawa 1974.

ZABŁOCKI, S. Postępowanie odwoławcze, kasacyjne i wznowieniowe w procesie karnym. Warszawa 1999, p. $90-99$.

ZALEŚNY, J. Charakter prawny Trybunału Stanu. Zagadnienia wybrane. Przegląd Sądowy. 2007, no $7-8$.

ZALEŚNY, J. Odpowiedzialność konstytucyjna w prawie polskim okresu transformacji ustrojowej. Toruń 2004. 
ZIĘBA - ZAŁUCKA, H. Formy odpowiedzialności konstytucyjnej w Rzeczypospolitej Polskiej, In: GRABOSKA, S; GRABOWSKI, R. Formy odpowiedzialności konstytucyjnej w państwach europejskich, Toruń 2010.

ZUBIK, M. Trybunał Stanu - stan Trybunału (Słów kilka o polskim sądzie nad notablami). In: SZMYT, A. Trzecia wladza. Sądy i Trybunały w Polsce. Materiały Jubileuszowego L Ogólnopolskiego Zjazdu Katedr i Zakładów Prawa Konstytucyjnego. Gdynia, 24 - 26 kwietnia 2008r., Gdańsk 2008. 